\title{
"What is it else?" Love's (Con-)Text in Romeo and Juliet
}

\author{
Aliakbari, H. ${ }^{1}$ and Abjadian, A. ${ }^{2}$ \\ ${ }^{1,2)}$ Department of Foreign Languages and Linguistics, Faculty of Humanities and Literature, Shiraz University, Eram Campus, \\ Eram Street, 7194684795, Shiraz, IRAN. \\ e-mails: aliakbari2007@gmail.com; aabjadian@rose.shirazu.ac.ir
}

\begin{abstract}
Reading Romeo and Juliet from Jacques Derrida's perspective provides us with new insight to Shakespeare's portrayal of love. As an early tragedy, Romeo and Juliet is a study of the nature of love. Many believe that the play still follows the lead of the comedies in presenting its major theme. However, drawing upon Derrida's deconstruction of the play, we have shown that love as an idea, a word, or a nomenclature, follows the same aporetic law of the proper name in that it is split, not unified, contradictory, not lucidly meaningful. We have demonstrated the multiplicity of love's identity despite the universally unifying attributes attached to it by the individual characters inside the play. In short, this reading reveals that identity in general, and the identity of love in particular, is not fixed, that they are products of textuality.
\end{abstract}

Key words: Romeo and Juliet, love, deconstruction, identity, name.

\section{INTRODUCTION}

Romeo and Juliet as an early tragedy published around the years (1595-96) is a study of the nature of love. It is a play about love before being about anything else and "This fundamental experience of deep and passionate love," to quote Clemen (1970), "is at the very base of the whole drama" (p. 69). It is the only tragedy in which Shakespeare makes his characters deal explicitly with the meaning of love ${ }^{\mathrm{i}}$. Romeo's outburst of oxymoron early in the play that leads to that less heeded question "What is it else?" (1.1.184) demonstrates Shakespeare's indulgence with the definition of love at the time when he was still busy with writing his Sonnets (1593-1609) and the play, $A$ Midsummer Night's Dream (1595-96), closely following some of his other comedies such as The Comedy of Errors (1593), The Taming of the Shrew (1593-94), and Love's Labour's Lost (1594-95). Hence, the play's characters and its style still partake of a tradition which mostly belongs to the world of comedy ${ }^{\mathrm{ii}}$. This would easily suggest that the love demonstrated in this tragedy should naturally follow the lead of the comedies and the tradition of the romantic poetry. However, the "death-marked love" of the Prologue in the outset of the play, and the fact that love has been set in the (con-)text of a tragedy, has already worked its way into the deconstruction of the very convention that the play is so heavily burdened with and crucially reliant upon. The play's simultaneous dependence and violation on/of the convention of love poetry are so confounding that lead the critics to contradictory remarks about it culminating in a kind of undecidability which dominates the play itself.

Bloom (1998), for instance, has discovered, in the relationship between Romeo and Juliet, "the largest and most persuasive celebration of Romantic love in Western literature" (p. 90) whereas Ryan (2002) has observed them, especially Romeo, "trapped inside the hackneyed role and ossified verse of the Petrarchan lover ... paralysed by the dead weight of clichéd paradoxes and inert metaphors, exiled from actual experience and emotions [italics added]" (p. 74). Love has sometimes been taken for life (Lecht, 1990, p. 184) and at times it has been regarded as an "urge towards death (White, 2001, p. 14). Such readings reveal that the text of the play has furnished the material for contrary interpretations of love. Our plan is therefore to uncover the hidden mechanism of the text that leads to such contradictions.

The search for the inherent contradictions of a text, which is one of deconstructionism's main concerns, may not satisfy a curious mind which looks for some novel ideas in a text, a mind which seeks discovery of an original subject or an illuminative explication that leads to new meanings. However, we may suffice to Belsey's (2002) explanation which takes the responsibility off our shoulders to justify the significance of our (deconstructive) reading. She writes:

Analysis reveals that at any given moment the categories and laws of the symbolic order are full of contradictions, ambiguities, and inconsistencies which function as a source of possible change. The role of ideology is to suppress these contradictions in the interests of the preservation of the existing social formation, but their presence ensures that it is always possible, with whatever difficulty, to identify them, to recognize ideology for what it is, and to take an active part in transforming it by producing new meanings. (p. 42) 
As she observes, the discovery of the contradictions in a text's structure is a means to destroy "the existing . . . formations" and to construct "new meanings" which is reminiscent of Harris's (2010) reference to deconstruction as a "portmanteau term that combines destruction and construction" (p. 43). The new meaning that deconstruction constructs is, however, not finalized and is itself subject to deconstruction.

Why deconstruction? To answer this question, we have to borrow Wolfreys' (1998) words as she writes: "The whole question of 'deconstruction' might be said to be one concerning identity. Is this a question of a particular identity? Does that identity exist? Is that identity discernible?" (p. 7).

Derrida's idea of deconstruction has a lot to say about identity which can eventually be applied to love, too. Deconstructionism reveals the inevitable duality of all kinds of identification because every word, even deconstruction, "carries with it its own 'deconstruction', its own possible semantic contradiction" (p. 53). It reveals the contradiction inherent in all names, the contradiction which remains invisible and transparent due to our desire for an immediate meaning. Love as a common name may follow the same contradictory law of the proper name. It is the law of contradiction because, as Derrida (2008) teaches us, in his article "Aphorism Countertime", the proper name is proper and common at the same time. "Aphorism," he writes, "is the name. . . . Aphorism is at once necessary and impossible. Romeo is radically separated from his name... but the separation, the aphorism of the name remains impossible" (p. 135). It seems that we are dealing with a new kind of fatalism (in its dual sense of being affected by the fate and of being mortal), the fate of the name or the name as fate. The Prologue best demonstrates it when the Chorus starts:

From forth the fatal loins of these two foes

A pair of star-crossed lovers take their life;

The phrase "take their life" has the double meaning of starting and ending, life and death at the same time. As Derrida (2008) concludes, "the lover's name is his essence [emphasis added]". ... Romeo exists in his name" (p. 136), which means "Romeo," the soul and flesh, dies, dissolves in/to, his name. Thus the problem of love which is directly connected with the problem of the name or with language in general will find another level of significance if we ask: What does love mean when the lovers' essence is the name?

This study finds significance in its attempt to find an answer or more specifically to show the difficulty of finding one for this question. To answer this question, we need to analyse the structure of the systems (here language or name) that, as in Atkins' (1991) words, "collapse differences into identities" ("Introduction," p. 14). Therefore, we will first demonstrate that language is the only thing that makes sense. Eventually, the idea of metaphysics that creates an illusion of reality and that presupposes the possibility of identification will be undermined. Secondly, we will investigate the text of the play to see in what different manners it presents the idea of love in general and the love between Romeo and Juliet in particular. Furthermore, the textual nature of the knowledge of love will be emphasized. Simultaneously, we will reveal that language falsifies and blurs the truth about the arbitrary and dual nature of the whole issue of identity itself.

\section{DISCUSSION}

\section{The Language That Makes Sense!}

Every object needs a name and nominations are inevitable. We have to name in order to know and to identify things or beings. "Language is experienced as a nomenclature," explains Belsey (2002) "because its existence preceded our 'understanding' of the world" (p. 43). As Wolfreys (1998) assents, "Conventionally language functions mimetically, or, at least, it is assumed to have this ability, to become a copy, to assume a likeness, of that which is not present, that which we seek to describe" (pp. 14-15). If we look at the issue from Hegel's perspective, "any particular experience can only be grasped by giving it a name [emphasis added] that is necessarily universal; and then bringing it into the movements of consciousness, or science, taken as a whole" (Stocker, 2006, p. 32). A better understanding of the generative function of the name, word, sound, etc., can be envisaged when looked at from the Platonist or Husserlian transcendentalist perspective which can be aligned with the transcendentalism of Descartes with a little modification: that is, I name therefore I am, you are, or it is. Thus the name becomes the source of genesis and existence.

Adam, for instance, in The Bible, demonstrates exactly the same kind of transcendental genesis when he gives "names to all cattle, and to the fowl of the air, and to every beast of the field" (Genesis 1:20, Authorized King James Version). As Brisman (1975) proclaims, "[i]n naming Eve, as in naming all animal life, Adam exercises his power of origination, his ability to share the creation with God" (p. 21 ). The act of identification is thus equated with the act of creation and implies that when we name something as something we assume to know that it exists, that we have access to its pure existence. In other words, in naming things we attempt to call them into life by addressing their pure materiality.

Addressing the materiality of the entities to fix their identities, however, from a deconstructive point of view, is just an illusion. When Juliet desires a separation between Romeo's name and Romeo himself, "O Romeo, Romeo, wherefore art thou Romeo? / Deny thy father and refuse thy name;" (2.2. 33-34), she actually attempts to reach the purity of the body, the purity of Romeo's self without "Romeo", a movement towards non-identity which is a movement towards non-signification. How can Romeo deny his name and still be Romeo? Her movement is in exactly opposite direction to that of Adam in The Bible. It is a movement in the direction of apocalypse and not that of genesis, a movement towards death.

Preservation of the name on Romeo's part, however, is quite paradoxically lethal, too. How can the name ascertain identity and/or being when the name is, in Derrida's (1982a) words, the "name of death" (p. 7). As he writes in "Aphorism 
Countertime," "Romeo is Romeo, and Romeo is not Romeo. He is himself only in abandoning his name, he is himself only in his name" (2008, p. 136). Derrida tries to say that an object is at the mercy of the "double aporia of the [. . .] name" (p. 138). He believes that Romeo and Juliet "will lose everything in this aporia, this double aporia of the proper name. And for having agreed to exchange the proper name of Romeo for a common name: not that of rose, but of love" (p. 138).

In fact, Derrida never denies the reality of the world and the things existing in it. The world and everything in it exist, but our access to them is through the name and/or text. Romeo exists but still he does so only in his name. This is in accord with Derrida's (1976) own famous declaration in $O f$ Grammatology where he expostulates that, "There is no outside (of the) text ('Il n y a pas de hors-text')" (p. 155). Waller (1991) points to the general misunderstanding on the part of some American scholars concerning the idea of the text. Thus, he remarks:

Derrida's famous "il n'y a pas de hors-text" can be read, not as too many of his American disciples have, as suggesting that there is nothing beyond text, but rather that there is only text, spatially and temporally, that the flow of textuality overflows the traditionally conceived barriers of the "text itself" and weaves us together in the flow of language which speaks us [emphasis added] and within which we struggle to speak. (p. 41)

Leitch similarly emphasizes the textual nature of all beings when commenting on Derrida's idea of deconstruction. "The world is text" he writes:

Nothing stands behind. . . . The concepts "being," "consciousness," "presence," and "self" are creations, fabrications, patchworks - interpretations. Functions not facts. Effects of language, not causes. . . . The text is not an autonomous or unified object, but a set of relations with other texts. (as cited in Booker, 1996, p. 59)

What we call by our language is not the same as what we see in the world. Our access turns out to be only to the text, to the sign, and not to the material world. Culler (1997) expostulates that "when you think you are getting outside signs and text, to 'reality itself', what you find is more text, more signs, chains of supplements" (p. 12). Derrida's (1976) assertion in Of Grammatology, "that the signified is originarily and essentially (and not only for a finite and created spirit) trace, that it is always already in the position of the signifier" (p. 73) indicates that sense, meaning, or signified is just an illusion or a mirage, "the mirage of the thing itself, of immediate presence, of originary perception" (p. 157). "The names of things," he writes, "do not belong to the things any more than the names of men belong to men (Derrida, 2008, p. 137). Romeo's speech best demonstrates this separation or alienation when he cries:

O tell me, Friar, tell me,

In what vile part of this anatomy

Doth my name lodge? Tell me, that I may sack

The hateful mansion. (3.3.105-108) (as cited in

Gibbons, 1980)
Romeo's speech shows the difference between the materiality the self, love, etc., and the metaphoric abstractness on the part of their form, the form that tends to be intrusive all the time and appropriate their purity. Lady Capulet's speech metaphorically demonstrates this relationship between the name as the cover and the love experience as the content and/or matter of the book of love:

Lady Capulet:

This precious book of love, this unbound lover,

To beautify him, only lacks a cover.

The fish lives in the sea, and 'tis much pride

For fair without the fair within to hide; (1.3.88-91)

The name does not exist in the body and naming alienates the thing from itself and sets it in the signifying texture of language. In this way, naming acts as a metamorphosis and transforms the pure object into a sign; the "precious book of love" turns the lover into the signifier of love, and love thus becomes a linguistic symbol. Being, therefore, becomes textual. As Lewis (2008) states:

We must know that linguistics' insight into the differentiality of the signifier demonstrates the impossibility of anything 'outside the text'. This amounts to saying that human beings have no access to anything non-textual, since the system of language cannot be given strict limits and is hence infinite" (p. 85).

Language, name, or text, becomes the aphoristic force of separation, alienation and the death of the self. What remains of the self is a trace that is left upon the palimpsest of language. However, there is a willingness on the part of the language users, to ignore the arbitrary connection between the name and the thing itself. The identification of the feeling (e.g., of love as lived experience) with/by a general concept, word, name, etc., is, therefore, shown to be equivalent to the Freudian notion of "after work". "We are always looking at an after work," Stocker (2006) explains,

the effects of the thought or the event in our memory, after the event. We always have a memory of the event, not the event itself, or even the original form of the memory. In its general usage, 'nachträglich' can be translated as additional or supplementary, something Derrida emphasizes. (p. 81)

To believe a one to one relationship between the signifier in language and its referent in the world is metaphysical in that one concept in the mind stands for a range of material objects in the world. Let us refer to an instance in the play when Romeo starts giving names to love:

Love is a smoke made with the fume of sighs,

Being purged, a fire sparkling in lovers' eyes,

Being vexed, a sea nourished with loving tears.

What is it else? a madness most discreet,

A choking gall, and a preserving sweet [our italics].

(1.1.181-185)

The nouns sit in the position of the subject complement in the statement "love is ..." and complete its structural gap; however, each statement separately assumes a saturation of meaning and thus brings the meaning of love into a closure. To say "love is a smoke" is a complete grammatical statement but it does not complete what love truly is. 
Meanwhile, Romeo's definitions relate love with some conventional concepts in the Renaissance England: the smoke of a sigh, the fire of the eyes, the sea of tears, etc. Convention reduces the lived experience into jargon clichés, into the same metaphysical vortex of reductionism that is the replacement of many by one observable in the Platonism of Saussure or of Husserl. "[Platonism or metaphysics]," Stocker (2006) observes,

places the one over the many, the essential unity of being over differences between beings. That extends into the static and a-temporal nature of language in Saussure that confirms the Platonist metaphysics, by placing what is unchangeable over time, or synchronic above changeability over time. (p. 29)

Language is metaphysical, hence reductive. It reduces an object to a linguistic sign and by doing so arrests its movement and eventually replaces it. The supplementary act of the name/sign/word or language in general obviates the need for the existence of what it calls. In a radical sense, therefore, one might agree that there is no the-thing-itself at all. The-thing-itself is a metaphysical assumption because it assumes a direct connection with the world and with the natural objects disregarding the intervention of language, signs, or symbols. It is in this sense that Derrida emphasizes the impossibility of escaping metaphysics. As he puts it in Of Grammatology, critiquing Saussure's concept of Language, "The system of language associated with phonetic-alphabetic writing is that within which logocentric metaphysics, determining the sense of being as presence, has been produced" (Derrida, 1976, p. 133). It is just determining the sense of being as presence, and not the being itself as present; the thing itself can never be present in the sign that represents it. Thus, we have only the representation of the things not the things themselves. The things themselves die in the transformative process of the objects' turning into linguistic signs. Derrida (1973) alleges that

My death is structurally necessary to the pronouncing of the I. . . The Bedeutung "I am" or "I am alive" or "my living present is" is what it is, has the ideal identity proper to all Bedeutung, only if it is not impaired by falsity, that is, if I can be dead at the moment when it is functioning. No doubt it will be different from the Bedeutung "I am dead," but not necessarily from the fact that "I am dead." (p. 96)

For Derrida, literal meaning is a myth. There is only metaphor, only the representation and/or interpretation. The name as a signature or a sign in a metaphoric move replaces its addressee. The message replaces the sender of the message. Identity becomes an effect of the name or of the text. Mere words or brief sounds are thus the determiners of the nature of one's state of being.

The destructive effect of the text is emphasized by the Prince of Verona early in the play when he censures the two families for causing confusion in the city just for an "airy word": "Three civil brawls, bred of an airy word, / By thee, old Capulet, and Montague" (1.1.80-86). Juliet's own punning on "I" and "ay" indicates how a single change of the form of a word, or even of a vowel, determines the significance of a being or non-being, hence the textual nature of existence itself:
Juliet:

Hath Romeo slain himself? Say thou but 'ay',

And that bare vowel ' $I$ ' shall poison more

Than the death-darting eye of cockatrice.

I am not I, if there be such an 'ay',

Or those eyes shut, that makes thee answer 'ay'.

If he be slain, say 'ay', or if not, 'no':

Brief sounds determine my weal or woe [italics added]. (3.2.45-51)

When only brief sounds determine one's fortune or misfortune, what is love then? How can we get to know it without the destructive effect of the text, or that of nomenclature? Is love possible at all?

The word love is a sign; it is not love itself. But language through illusion of reality or what Derrida calls metaphysics of presence creates a false presence in the consciousness as though the word were exactly the feeling of love experienced in the body, mind, and soul. Romeo's question, "What is it else" points to love's being always something else which makes it temporally and spatially aloof from itself. In other words, the answer to Romeo's question is always at the mercy of the text's supplying meaning for it and since meaning is subject to change due to the change of the context, love's meaning is also subject to change. Waller's (1991) observation may be taken as a truth universally acknowledged that "at the very heart of the wished-for fullness of language, is its betrayal" (p. 25).

Romeo and Juliet demonstrates this betrayal of love by situating it in the names; the names, language's so-called pronouncers of identity, are the betrayers of those very identities that they bestow upon the things. This is because all the names are marked with incompletion and reduction; they are marked with the possibility of being always (the trace of) something else.

\section{The Double Aporia of the Name}

Love in this play is presented in two forms: the universal love which appeals to the people's common knowledge of it, the kind of love that is linked with the traditional ideologies known to the people of Verona on the one hand, and the personal love that has to be experienced solely in the body, and quite ironically, without the possibility of sharing it with someone else on the other. In the former case, love becomes easily predictable as if the people who were referring to it were themselves sages in the field or science of love. In the latter case, love is an unnamable experience, a nothing that is everything and everything that is nothing, "that is not what it is" (1.1.165) in Romeo's words; it is something that cannot be put into words or described. The Bible's "bone of my bones, and flesh of my flesh . . . they shall be one flesh" (Genesis. 1:23-24, Authorized King James Version) refers to a kind of pure materiality which is absent in the sign, which is not present except in the form of abstract symbols (representation) in language.

In its universal and abstract form, love is related with melancholy, sickness, madness, Eros as the life force, and with thenatos or the death wish. All these in some way or 
another appear in Romeo and Juliet. Early in the play, Romeo's love for Rosaline is identical with melancholy or sickness in Benvolio's speech (1.1.109-121) which is a very common idea in the Renaissance England. As Dickey (1966) confirms, quoting from Burton's Anatomy of Melancholy, "Love is a species of melancholy ... The belief that love is a disease," he continues, "is old, much older indeed than the Renaissance" (p. 28). He retains that Elizabethans "exhibited" those who died for love "as patterns to pity but to shun" (p. 35), hence Benvolio's speech, "And gladly shunned who gladly fled from me" (1.1.121). That is probably why Romeo's father thinks of a cure for his son taking his sickness for granted (1.1. 132133, 142-146). Montague's "the bud bit with an envious worm" (1.1.142) refers to Romeo's body as a plant that has been infected with (love as) a disease. The disease of love is also with a little variation implied in Friar Lawrence's interior monologue in (2.3.1-30). Love has universally been identified with melancholy, sickness, or disease. The idea of love-sickness is still a common knowledge. "Such love is an infectio," argues Dickey (1966), "or disease . . . which is all too easily caught and once caught hard to cure" (p. 24). When Benvolio attempts to encourage Romeo to find a new love as a cure to his old unacknowledged one for Rosaline, he subconsciously links it again with a disease (of the eye):

Take thou some new infection to thy eye,

And the rank poison of the old will die. (1.2.48-49)

Romeo's reply shows his early obsession with the universal common knowledge of love as immortal beauty:

Romeo:

One fairer than my love ! the all-seeing sun

Ne'er saw her match since first the world begun. $(1.2 .92-93)$

His idealization of love is in line with the Platonic love of Beauty as the ultimate goal of the lover. He is repeating the same teleology recurrent in Diotima's advice to Socrates in Plato's Symposium:

In the activities of Love, this is what it is to proceed correctly, or be led by another: Beginning from beautiful things to move ever onwards for the sake of that beauty .... to come finally to that understanding which is none other than the understanding of that beauty itself, so that in the end he knows what beauty itself is. (Cobb, 1993, p. 48)

Mercutio refers to the mythic background of love which is still common knowledge in Verona, that love is divine.

Mercutio: You are a lover, borrow Cupid's wings,

And soar with them above a common bound.

(1.4.17-18)

His "common bound" refers to the bound of humanity. Romeo can defy all human boundaries through being a deity of love. Mercutio also relates love with fancy, with the world of imagination or dream, and hence with madness which is induced by the magic potion of Qeen Mab, the queen of all illusory and dreamy artifices of the mind who "gallops night by night / Through lovers' brains, and then they dream of love" (1.4.70-71). The universal love resides in the immutable world of the immortal dreams. It is not subject to change and reaches a level of idealism which trespasses the limits of earthly experience. Romeo's idea- listic infatuation with Rosaline's love does not change when his love switches towards Juliet. He still shows a transcendental attachment to the ideal beauty:

Romeo: O she doth teach the torches to burn bright!

It seems she hangs upon the cheek of night

As a rich jewel in an Ethiop's ear -

Beauty too rich for use, for earth too dear:

So shows a snowy dove trooping with crows,

As yonder lady o'er her fellows shows.

The measure done, I'll watch her place of stand,

And touching hers, make blessed my rude hand.

Did my heart love till now? forswear it, sight!

For I ne'er saw true beauty till this night. (1.5.43-52)

Thus the physical and spiritual has been taken to be metaphysically present and unifiable. His poetic and lyrical fervor has even found a more vigorous and fanciful articulation. The speech, however, is contradictory because the ideal and real, the universal and particular are desired simultaneously. Romeo is speaking about a beauty "too rich for use," and at the same time, talks about touching "hers, [and] make blessed my rude hands." That is probably why critics like Bate and Rasmussen (2007) believe that he is "in love with the idea of being in love" (p. 1676), and not in love with Rosaline or Juliet.

Yielding to the universal notions of love is one of the main features of the characters in the play. Besides Montague and Benvolio, we can find similar attachment to the universality of love on the part of Capulet, Mercutio, the Friar, or even on that of Romeo and Juliet themselves. Love in this play is once a mythic spell caused by a dart shot from a wanton god's arrow and once a conventional emblem of Platonic ideal beauty (1.1. 160-161, 199-207). It is at times tender and at times tyrannous and rough. Romeo wonders about the quality of its being when he asks, "Is love a tender thing? it is too rough, / Too rude, too boist'rous, and it pricks like thorn" (1.4.25-26). The undecidability reaches its climactic point when it becomes identical with its opposite, with what it is not, hence another contradictory situation:

Juliet: Not proud you have, but thankful that you have: Proud can I never be of what I hate,

But thankful even for hate that is meant love [our emphasis]. (3.5.146-148)

Hate is absence of love, and since love is typically identified with life, absence or hate is identified by death. As Derrida (1982b) intimates, "absence is not a continuous modification of presence; it is a break in presence, 'death', or the possibility of the 'death" (p. 316). It is death that finally and ironically represents and contains love in an act of appropriation.

Romeo: .................... Shall I believe

That unsubstantial Death is amorous,

And that the lean abhorred monster keeps

Thee here in dark to be his paramour? (5.3.103-105)

This is how the play deconstructs the whole Renaissance notion of love as life, as the animating force that binds the lovers and immortalizes their souls, the happily ever after of the world of comedies which cannot happen in this tragedy. Paris's speech, "O love ! O life ! not life, but love in death!" (4.5.54-58), associates love with death which from the point 
of view of the Renaissance mentality can be regarded as a contradiction. As Bates (2002) notes, "'Tragedy of love' is to some extent a contradiction in terms. For love is the great force that unites and binds. It is what prompts a man to leave his father and mother and cleave to his wife" (p. 182).

Name, whether proper like Romeo and Juliet or common like love, is contradictory. It is marked with both life and death. As Kamuf (2001) asserts, "the names we give to love when we declare love to another by addressing him or her by name, we address it also [emphasis added] to his or her mortality" (p. 159). The young lovers, Romeo and Juliet, best demonstrate subconscious juxtaposition of love and death when they speak of death exactly the moment they are thinking about love or about union with each other (2.6.3-4, 3.2.20-22). As Kristeva consents, "The fact remains that Juliet's jouissance is often stated through the anticipation - the desire? - of Romeo's death. This [happens]," she continues, "long before her drugged sleep deceives Romeo and leads him to suicide . . .: 'Methinks I see thee, now thou art below, as one dead in the bottom of a tomb' (3.5.55-6)" (as cited in White, 2001, p. 79). "[Romeo] is doomed [voué] to death," writes Derrida (2008), "and [Juliet] with him, by the double [emphasis added] law of the name" (p. 139). "They shall be one flesh" but ironically united in their death bed.

So far we have enumerated the universal attributes of love in the play. They are, nonetheless, challenged by the text of the play from the very beginning in a way that the universal unity of the identity of love becomes impossible.

From the very beginning, love is depicted as the experience of one and only one person, an idiomatic and singular event that is hard to put into words unless one finds himself in a contradictory situation reflected in Romeo's paradoxical expressions. His set of oxymoron early in the play sets love in a personal and paradoxical context:

Romeo:

Why then, O brawling love, O loving hate,

$\mathrm{O}$ any thing of nothing first create!

O heavy lightness, serious vanity,

Misshapen chaos of well-seeming forms,

Feather of lead, bright smoke, cold fire, sick health, Still-waking sleep, that is not what it is! [emphasis added] (1.1.162-165)

His oxymoronic combination of the opposing words is a parody of the humanistic essentialism of the Renaissance culture that favored "seriousness, to vanity", "well-seeming forms" to "misshapen chaos", etc. Romeo's use of puns reveals the duality inherent in language itself.

Love is never one thing. In fact, as Dickey (1966) also avers, "love was not one but many things" (p. 26). It cannot be easily substantiated, defined and hence felt as containable. It is "Too flattering-sweet to be substantial [italics added]" (2.2.125-135) as Romeo intimates. In his emotional attachment to Rosaline, his play upon language is in the form of a kind of destabilization of meaning. The plurality bestowed upon love through metaphors, puns, and oxymoron destabilizes language's metaphysical grip to meaning because "Metaphor is an expression of the force of language," Stocker (2006) asserts, and is the only way in which language can pass from one existing thing, or meaning, to another. . . . "(p. 158). How can one name a thing which is not fixed in meaning? Moreover, every person's different experience of love has its own idiomatic character that makes each and every feeling distinct and indescribable. Romeo's love for Rosaline is different from that for Juliet. In addition, Romeo and Juliet appear to experience different kinds of love each in person. Romeo's reply to Friar Lawrence is good evidence of this singularity of the experience of what we call love in general:

Romeo: Thou canst not speak of that thou dost not feel.

Wert thou as young as I, Juliet thy love,

An hour but married, Tybalt murdered,

Doting like me, and like me banished,

Then mightst thou speak, then mightst thou tear thy hair,

And fall upon the ground as I do now,

Taking the measure of an unmade grave. (3.3.61-70)

The experience of love is thus associated with and connected to lots of other personal experiences that thinking of it as a general ideal concept proves to be not creditable. Romeo connects his experience of love with his being young, with Juliet specifically being his love, with his late marriage, with his act of murder, with his passion and his banishment at the same time. All these together record the singularity of his love experience. No one else can have the same experience in the same conditions that he is in. That is probably why a philosopher like Derrida (2011) refrains from offering a general definition for love. He says in an interview, "I have nothing to say about love. . . . I can't examine 'love' just like that. ... I'm not capable of talking in generalities about love. . . . I have an empty head on love in general". His emphasis on the word "general" confirms the singularity of the experience of love which is different from what it is called in language. If he spoke about love in general terms, then he would "just be reciting clichés."

Derrida eschews generality because in generalities language performs its metaphysical role to gather up and close the horizon as does the name/aphorism. In his short explanation, he tries to avoid running the risk of defining the thing which is not definable, naming the thing that should remain unnamable. As Derrida (1987) affirms, we love the one without concern for the name: "But it is you that I love, the living one. Beyond everything, beyond your name, your name beyond your name" (p. 144). Love like the substance that bears it has nothing to do with any identity; therefore, it is not closed off in meaning. As Juliet also attempts to relate, love can neutralize and transgress the closure of the name:

Juliet: O Romeo, Romeo, wherefore art thou Romeo?

Deny thy father and refuse thy name;

Or if thou wilt not, be but sworn my love,

And I'll no longer be a Capulet. (2.2.33-36)

The dichotomy between the form, appearance, cover, title, name, or as Juliet puts it, "show" and the matter, substance, etc., thus sets in to be the main source of undecidability in this tragedy. She, eventually, falls into the same rash of paradoxes that we see Romeo articulate early in the play (2.2.73-81). Thus, love is always death and life, joy and sorrow, bitterness and sweetness, madness and discretion, 
heaven and hell, angel and daemon, immortality and mortality together; it is always similitude and difference at the same time. "Was ever book containing such vile matter / So fairly bound? [emphasis added] Juliet asks. "O that deceit should dwell / In such a gorgeous palace" (2.2.8284). Romeo's question, "What is it else?" (1.1.184) early in the play foresees an infinite range of possibilities that is in contrast with the simultaneous finitude and closure of the text's/name's desire for the immediacy of meaning which happens at the end of the play when the Prince declares the morale of the event of love and sums up its meaning in the form of a short epilogue:

See what a scourge is laid upon your hate,

That heaven finds means to kill your joys with love; (5.3. 291-292)

Thus love is ironically reduced to a means of punishment rather than reconciliation and redemption as expected from it in the Renaissance context. However, White does as much leave the question "What is this thing called love?" un-answered as does Romeo or the text of the play. "So radically multiple are the associations of 'love' and 'desire'," White (2001) expostulates, "that we find ourselves circling around an absent centre of meaning [italics added], an evacuation" (p. 5). This is in accord with the multiplicity of love's appearance in different contexts changing colors like a chameleon. Irving Singer [in his The Nature of Love] has listed some kinds of love that we habitually speak of:

Love of self, of mankind, of nature, of God, of mother and father, of children, of tribe and nation, of sweetheart or spouse or sexual idol, of material possession, of food or drink, of action and repose, of sports, of hobbies or engrossing pursuit, of justice, of science, of truth, of beauty, and so on endlessly. Each variety of love, involving it special object, has its own phenomenology, its own iridescence within the spectrum that delimits human experience. (as cited in Nordlund, 2007, p. 21)

As Singer shows, love is various and refers to a range of different human experiences. Plato in his Symposium also refers to the ambiguity concerning the idea of love when Pausanias retorts to Phaedrus's injunction to praise love: "If Love were a single being, it would be fine, but as it is, there isn't just one of him. And since there isn't, it would be more correct to say first which particular Love we ought to praise" (Cobb, 1993, p. 21). Derrida's argument that love is always divided between the love of who and of what testifies to the divided nature of love's identity. "That is to say," he asserts,

the history of love, the heart of love, is divided between the who and the what. . . . I speak of it abstractly, but I think that whoever starts to love, is in love, or stops loving, is caught between this division of the who and the what. One wants to be true to someone - singularly, irreplaceably - and one perceives that this someone isn't $\mathrm{x}$ or $\mathrm{y}$. (Derrida, 2011)

In a radical level, then, dealing with the problem of identity might be found "foolish" because, "an identity is never given, received, or attained" (Derrida, 1998, p. 10). Derrida asserts that "only the interminable and indefinitely phan- tasmatic process of identification endures [italics added ]" (p. 28). The word phantasm implies the illusiveness of identity or the state of being identified, hence its dictionary meaning: "An illusion, an appearance that has no reality; a deception, a figment; an unreal or imaginary being, an unreality; a phantom" (OED). Besides, the statement just quoted indicates that there is only the "process" of becoming and not the state of being, change, not fixity, and the process of identification, not identity. Thus the identity of love is always on the move, hence Romeo's question, "What is it else?"

\section{CONCLUSION}

Shakespeare challenges our romantic idealism by his realistic depiction of the nature of human relationship and that of human love. He demonstrates that love is essentially re-presentable through a/the text. We may eschew the sovereignty of the text or nomenclature only through the escape to non-signification, to death.

Romeo finally dies for a love which he does not know what it is. His movement from the love for Rosaline to his love for Juliet and from thence to his death is a movement in a permanent acceptance and repudiation of the conventions of love; it is an oscillation between the universal and personal experiences of love where Verona's etiquette of family name and its social function finally pave the way towards a secluded sepulcher where the lovers dead bodies ironically unite. The play demonstrates the ancillary nature of identity with regard to the sovereignty of language and of the name. The only thing that is accessible is the name of a being or thing. Romeo must die. His name will live forever. Love itself must be wedded to the amorous death. Love as the name of all the diverse human desires shall remain to be yet deciphered in different con-texts.

\section{REFERENCES}

Atkins, G. D., \& Bergeron, D., M. (1991). Shakespeare and deconstruction. New York: Peter Lang.

Bate, J., \& Rasmussen, E. (Eds.) (2007). William Shakespeare's complete works. Hampshire: Macmillan.

Bates, C. (2002). Shakespeare's tragedies of love. In C. McEachern (Ed.), The cambridge companion to Shakespearean tragedy (pp. 182-203). Cambridge: Cambridge University Press.

Belsey, C. (2002). Critical practice. London and New York: Routledge.

Bevington, D. (2002). Tragedy in Shakespeare's career. In C. McEachern (Ed.), The cambridge companion to Shakespearean tragedy (pp. 50-68). Cambridge: Cambridge University Press.

Bloom, H. (1998). Shakespeare: The invention of the human. London: Fourth Estate Limited.

Booker, M. K. (1996). A practical introduction to literary theory and criticism. New York: Longman.

Brisman, L. (1975 Spring). At thy word: A reading of Romeo and Juliet. Bulletin of the Midwest MLA, 8 (1), 21-35.

Charlton, H. B. (1970). Shakespeare's experimental tragedy. In D. Cole (Ed.), Twentieth century interpretations of 
Romeo and Juliet: A collection of critical essays (pp. 49-60). New Jersey: Prentice-Hall, Inc.

Charney, M. (2000). Shakespeare on Love and Lust. New York: Columbia University Press.

Clemen, W. H (1970). Romeo and Juliet. In D. Cole (Ed.), Twentieth century interpretations of Romeo and Juliet: A collection of critical essays (pp. 66-75). New Jersey: Prentice-Hall, Inc.

Cobb, W. S., (Trans.). (1993). The symposium and the phaedrus: Plato's erotic dialogues. New York: State University of New York Press.

Culler, J. (1997). Literary theory: A very short introduction. Oxford: Oxford University Press.

Derrida, J. (1973). Speech and phenomena. (D. B. Allison, Trans.). Evanston, IL: Northwestern University Press.

Derrida, J. (1976). Of grammatology. (G. C. Spivak, Trans.). Baltimore, MD: John Hopkins Press.

Derrida, J. (1982a). The ear of the other: Otobiography, transference, translation. New York: Schocken Books.

Derrida, J. (1982b). Margins of philosophy. (A. Bass, Trans.). Chicago: The University Chicago.

Derrida, J. (1987). The post card: From Socrates to Freud and beyond. (A. Bass, Trans.). Chicago, IL: Chicago University Press.

Derrida, J. (1998). Monolingualism of the other; or, the prosthesis of origin. Stanford, California: Stanford University Press.

Derrida, J. (2008). Psyche: Inventions of the other. Vol. II. Stanford, California: Stanford University Press.

Derrida, J. (Speaker). (2011, Jan. 26). On love and being [Video file]. Retrieved from http://www.youtube.com/ watch? $\mathrm{v}=\mathrm{dj} 1 \mathrm{BuNmhjAY}$

Dickey, F. M. (1966). Not wisely but too well: Shakespeare's love tragedies. San Marino, California: The Huntington Library.

Gibbons, B. (Ed.). (1980). Romeo and Juliet. ( $2^{\text {nd }}$ series). London: Methuen. The Arden Shakespeare.

Harris, J. G. (2010). Shakespeare and literary theory. Oxford: Oxford University Press.
Kamuf, P. (2000). Deconstruction and love. In N. Royle (Ed.), Deconstructions: A user's guide (pp. 151-70). New York: Palgrave.

Lecht, J. (1990). Julia Kristeva. London and New York: Routledge.

Lewis, M. (2008). Derrida and Lacan: Another writing. Edinburgh: Edinburgh University Press.

McAlindon, T. (2002). What is a Shakespearean tragedy? In C. McEachern (Ed.), The cambridge companion to Shakespearean tragedy (pp. 1-22). Cambridge: Cambridge University Press.

Nordlund, M. (2007). Shakespeare and the nature of love: Literature, culture, evolution. Illinois: Northwestern University Press.

Oxford English Dictionary (2009). (2 ${ }^{\text {nd }}$ ed.). [CD-ROM]. Vol. 4.0.0.2. Oxford: Oxford University Press.

Ryan, K. (2002). Shakespeare. ( $3^{\text {rd }}$ ed.). Hampshire and New York: Palgrave.

Snyder, S. (1979). The comic matrix of Shakespeare's tragedies: "Romeo and Juliet", "Hamlet", "Othello" and "King Lear". Princeton, New Jersey: Princeton University Press.

Spurgeon, F. E. (1970). Light images in Romeo and Juliet. In D. Cole (Ed.), Twentieth century interpretations of Romeo and Juliet: A collection of critical essays (pp. 61-65). New Jersey: Prentice-Hall, Inc.

Stocker, B. (2006). Routledge philosophy guidebook to Derrida on deconstruction. London and New York: Routledge.

The Bible: Authorized King James version (1997). With an introduction and notes by Robert Carroll and Stephen Prickett. Oxford: Oxford University Press.

Waller, G. (1991). Decentering the bard: The dissemination of the Shakespearean text. In D. Cole \& David M. Bergeron (Eds.), Shakespeare and deconstruction (pp. 21-46). New York: Peter Lang.

White, R. S., (Ed.). (2001). Romeo and Juliet: New casebooks. Hampshire and New York: Palgrave.

Wolfreys, J. (1998). Deconstruction: Derrida. London: MacMillan Press Ltd.

\footnotetext{
${ }^{i}$ Note the determined expostulation on the part of Clemen and us as if we knew what love was. We will try to demonstrate in the course of this study that speaking about love in a determined tone originates from an inescapable metaphysics inherent in language.

${ }^{\text {ii }}$ For more information on the play's generic ambiguities you can consult H. B. Charlton 49ff; Franklin M. Dickey 65ff; Kiernan Ryan 67-72; Tom McAlindon 1-22; David Bevington 53-55, Maurice Charney 79-88, Susan Snyder 19-28, just to name a few). For its poetic and lyrical qualities and rich imagery see Spurgeon $61 \mathrm{ff}$ and W. H. Clemen 66ff.
} 